\title{
Developmental Characteristics of Spelling Ability of Kindergarten to 3rd Grade Children
}

\author{
Kyung Hee Jung \\ Department of Speech and Language Pathology, Graduate School of Rehabilitation and Welfare, Yongin University, Yongin, Korea
}

Correspondence: Kyung Hee Jung, $\mathrm{PhD}$ Department of Speech Language Rehabilitation, Yongin University, 134 Yongindaehak-ro, Cheoin-gu, Yongin 17092, Korea

Tel: +82-31-8020-2864

Fax: +82-31-8020-3075

E-mail: 1012jkh@hanmail.net

Received: January 21, 2019

Revised: February 21, 2019

Accepted: March 4, 2019

This work was supported by research grants from the Yongin University in 2017.

\begin{abstract}
Objectives: The purpose of this study is to investigate the developmental characteristic of spelling ability according to the types of spelling and phonological rules of kindergarten children to 3 rd grade children. Methods: The subjects were 148 typically developmental children, including 40 kindergarten, 46 1st grade, 35 2nd grade, and 373 rd grade children. The research tool consisted of word spelling with four spelling types and four phonological rules. Results: First, as the children's age increases, spelling performance increases according to the spelling types or phonological rules. There was no statistically significant difference between the second and third graders in elementary school, but all the other groups showed statistically significant differences. Second, the differences of the remaining spelling types, except for the letter-phoneme incongruent and single final consonant were significant. There was a significant difference between the letter-phoneme correspondence words in kindergarten and elementary first graders, and the letter-phoneme incongruence double final consonant were significant in all grade levels. Third, the performance of the children according to the phonological rules was high in order of nasalization, lenition, fortification, and aspiration. Conclusion: Through the results of this study, we can understand the characteristics of spelling development from kindergarten through elementary school. Implications for spelling writing and intervention are discussed.
\end{abstract}

Keywords: Kindergarten, School-aged children, Spelling, Types of spelling, Phonological rules
학령기 아동의 읽기와쓰기는 교과과정의 기본을 이루며 학업성 취뿐 아니라 학교생활을 성공적으로 수행하기 위해서 주요하게 습 득해야 하는 기술이다. 읽기와 쓰기는 서로 밀접한 관계가 있을 뿐 아니라 서로 영향을 주고받기 때문에 쓰기에 문제가 있으면 읽기에 도 문제가 있다(Cho \& Kim, 2000). 특히 쓰기는 말하기, 듣기, 읽기 등의 기술이 서로 통합하면서 발달하기 때문에 읽기능력보다 배우 는데 더 어려운 기술이며, 학령기뿐 아니라 전 생애에 걸쳐 습득해 야 하는 주요한 능력이다(Kim, 2013). 쓰기는 일반적으로 글씨쓰 기, 철자쓰기, 작문으로 나누어지며 쓰기의 궁극적인 목적은 작문 이다. 이러한 작문기술을 습득하기 위해서는 소리정보를 글자로 부 호화하는 과정이 필수적으로 요구되는데 이 과정에서의 핵심이 철 자쓰기 기술이다. 따라서 철자쓰기는 초기 읽기, 쓰기 발달에 있어 중요한 요인으로 작용한다(Kamhi \& Catts, 2012).
철자쓰기는 자신이 전달하고자 하는 메시지를 소리정보로 표상 하고 이를 부호로 변환시키는 과정을 통해 독자가 이해할 수 있는 정확하고도 신뢰로운 메시지를 전달하는 기술이다. 그런데 이러한 철자쓰기의 어려움이 생기면 글의 주제와 관련된 내용을 생성하거 나 계획하는 데 방해가 되고, 생각하는 내용을 정확하고 풍부하게 표현할 수 있는 기회를 잃어버리게 된다(Park \& Chung, 2008). 철 자쓰기는 철자의 구조에 대한 고도의 감각을 요하는 언어기술로 특정 단어에 대한 철자쓰기가 가능하기 위해서는 음운론, 철자법, 형태론, 의미론에 대한 언어지식 단위를 인식하고 사용할 수 있어 야 한다(Kamhi \& Catts, 2012). 지금까지 많은 연구자들은 모든 언 어권의 표기체계에서 음운인식, 형태인식, 철자표기 인식능력이 철 자쓰기 기술을 예측하는 요인이라는 데 동의하고 있다(Yang \& Lee, 2016). 즉 철자쓰기 능력의 발달은 이러한 상위언어 능력의 발 
달과 긴밀히 연관되어 있다(Ehri, 1985; Nagy, Berninger, \& Abbott, 2006). 이처럼 철자쓰기는 학령기 아동이 교과과정을 학습할 때 중 요한 역할을 하기 때문에 아동들이 철자쓰기를 어떻게 습득해 나 가는가를 이해하는 것은 학업성취 및 학교적응 능력을 이해하고 평가할 때 매우 중요하다.

지금까지 많은 연구자들은 초기 철자쓰기 기술의 발달에 많은 관심을 보여 왔으며 이러한 발달의 특성을 설명하는 관점들은 크 게 두 가지로 나눠볼 수 있다. 즉 초기 철자쓰기 학습과정이 일련의 단계를 거쳐 발달하게 된다는 단계이론(Gentry, 1982)과 어린 아동 들도 철자쓰기의 비음운론적 양상인 형태론적 정보나 철자패턴 등을 알고 있다는 이론(Daffern, Mackenzie, \& Hemming, 2015; Yang, 2014)이 그것이다. 단계이론을 주창하는 연구자들은 음운처 리, 표기처리, 형태처리 단계로 나아가는 연속적인 과정으로 철자 발달 과정을 설명하고 있다(Bear, Invernuzzi, Templeton, \& Johnston, 2012; Gentry, 2000). 이들은 철자오류 분석을 통해 한 단계에 서 다음 단계로의 철자쓰기 능력의 발달은 질적으로 다르지만 연 속적으로 나아가는 과정이며, 중재의 초점도 다음 단계로 나아가도 록 하는 데 있다는 점을 강조하였다(Bear et al., 2012; Gentry, 2000). 단계론자들의 주장은 철자오류 분석을 통해 영어의 과거시제를 쓸 때 어린 아동이 음성적으로 전사한다는 연구결과나(Read, 1986), 6-8세 아동이 초기는 음소나 형태소 성분을 반영하지 못하다가 8 세경 음소성분을 반영하지만 불규칙 단어까지 과잉 적용하는 단계 를 거친 후 규칙단에만 적용하는 방식으로 발달한다는 연구결과 에 근거하고 있다(Nunes, Bryant, \& Bindman, 1997). 또한 Henderson (1990)은 철자발달 초기에는 음운전략을 사용하다가 만 7, 8 세 이후 형태전략을 철자쓰기에 적용한다고 주장하기도 하였다.

반면 음운인식, 형태인식, 철자표기 인식능력이 철자쓰기 발달 초기부터 상호작용하고 통합될 수 있다는 점을 강조하는 연구자들 은 철자 발달의 비선형모델(non-linear model)에 대한 근거를 다양 하게 제기하고 있다(Daffern et al., 2015; Rubin, 1988; Treiman, Cassar, \& Zukowski, 1994). Rubin (1988)은 어린 아동들도 하나의 형태소로 이루어진 단어(hand)에서의 끝자음 생략이 굴절접사가 포함된 두 개의 형태소로 이루어지는 단어(canned)에서보다 생략 을 더 많이 한다는 점을 들어 초기 철자쓰기부터 형태구조가 영향 을 미친다는 점을 보고하였다. 또한 5세에서 9 세 아동을 대상으로 형태소 하나로 이루어진 단어와 두 개로 이루어진 단어쓰기 과제 (예: letter와 later)를 실시한 결과 1학년 아동들도 철자쓰기에서 형 태소 지식을 활용한다고 주장하기도 하였다(Treiman et al., 1994). 한편 겹자음 생략 오류분석을 통해 형태소가 하나인 단어(brand) 에서보다 형태소가 두 개인 단어(tuned)에서 첫 자음의 생략이 적
었다는 실험결과를 통해 초기 음운지식이 적용되는 시기에도 어린 아동들에게 형태지식이 영향을 미친다는 점을 주장하기도 했다 (Treiman et al., 1994). 또한 Berninger 등(2006)은 삼중 단어구성 이론(triple word-form theory)을 기반으로 음운인식, 철자표기인 식, 형태인식이 초기 쓰기 학습부터 상호 관련된다고 주장하였다. 지금까지 살펴본 철자쓰기 발달에 관한 다양한 관점들은 음운지 식을 활용한 쓰기가 철자발달 시작 과정에서 먼저 나타난다는 점 에서는 동의하고 있다. 하지만 형태지식이나 철자표기지식이 초기 부터 철자쓰기에 영향을 미치는지 여부에 관해서는 의견을 달리하 고 있다.

한편 최근 국내에서도 철자쓰기 발달 과정을 언어학적 지식과 관련시켜 설명하고자 하는 움직임이 몇몇 연구자들에 의해 나타나 고 있다. 초등 저학년의 철자발달 과정을 살펴본 Yang (2014)은 철 자유형이 음운론적 유형과 형태론적 유형으로 나눌 수 있으며 초 등 1학년부터 음운론적 유형의 철자 정확도가 높고 형태론적 유형 보다 앞섰다고 보고하고 있다. 음소인식, 형태소인식, 철자표기인식 의 영향력이 1 학년 때는 비슷하다가 학년이 높아지면서 철자표기 인식의 영향력이 증가했다는 Yang과 Lee (2016)의 연구도 언어학 적 지식능력과의 관련성을 보고하고 있다. 하지만 국내에서는 철자 쓰기 발달 연구가 많지 않을 뿐 아니라 영어권 연구에서 쟁점이 되 고 있는 언어학적 지식과 초기 철자쓰기 발달과의 관련성을 다룬 연구는 미비한 실정이다. 이에 본 연구는 유치원 시기부터 초등 저 학년 시기 동안 음운지식과 형태지식이 철자쓰기 발달에 어떤 관 련을 나타내는지를 살펴보고자 하였다.

지금까지 대부분의 철자쓰기 발달에 대한 국내연구는 단어나 문장 받아쓰기에서 나타난 아동의 철자오류 분석방법을 중심으로 주로 연구되어 왔다. Lee (2018)는 초등 1학년에서 6학년에 이르기 까지 일반아동의 철자쓰기 능력을 비교하였는데 5, 6학년 집단을 제외한 모든 학년 집단의 쓰기 점수 차이가 유의하게 나타났다. 또 한 학령전기 아동은 소리 나는 대로 쓰기 오류가 가장 많이 나타났 으며, 소리 나는 대로 쓴 오류는 연령이 증가할수록 감소하고 대치 오류가 증가하였다고 하면서 초기에 음운지식의 사용이 보편적 현 상임을 강조하였다(Jung, 2005). 또 다른 연구자는 초등학교 3학년 까지는 철자쓰기 정확률이 유의하게 증가하는 발달 양상을 보이지 만 4학년 이후는 학년 간의 차이가 유의하지 않으며 완만한 성장을 보인다고 하였다(Shin, Seol, Cho, Nam, \& Pae, 2015). 또한 같은 연 구에서 자소-음소 일치 오류, 자소-음소 불일치 오류, 문법형태소 오류로 나눠 분석한 결과 모든 학년에서 자소-음소 불일치 오류가 가장 많았으며 이는 3 학년 시기에 크게 감소하였으나 이 시기에 문 법형태소 오류는 증가하는 경향을 보인다고 보고하였다(Shin et 
al., 2015). 초등 1-4학년의 철자인식과 철자쓰기를 연구한 Chung (2015)은 철자인식능력은 저학년과 중학년 간 유의한 차이가 있었 으나 철자쓰기 과제에서는 유의한 차이가 없었다고 하였다.

반면 최근 철자전략 사용능력의 발달적 특성을 알아보기 위해 음운처리 능력뿐 아니라 형태처리 능력을 적용하는 철자쓰기 평가 방법을 제안한 몇몇 연구자들이 있다(Deacon \& Bryant, 2005; Han \& Jung, 2018; Sangster \& Deacon, 2011). 이들은 규칙단어, 불규칙 단어, 한 소리를 내는 두 글자가 들어간 단어 등을 이용해 철자전략 의 특성을 살펴보았다(Masterson \& Apel, 2007). 또한 철자검사를 1 형태소와 2형태소를 나누었으며, 2형태소는 다시 접사가 포함된 굴절어와 파생어로 나누어 살펴보았다. 또한 통제단어를 두 형태소 단어 중 하나와 같은 단어-소리로 끝나도록 통제하였으며(예: corner vs. smarter), 철자검사에 사용된 단어는 난이도와 단어의 빈도 가 균형을 이루도록 고려하였다(Deacon \& Bryant, 2005; Sangster \& Deacon, 2011). 국내에서도 음운론적 유형과 형태론적 유형을 포 함한 철자쓰기 과제를 개발하여 이 두 가지 유형의 철자쓰기 발달 특성을 다루거나(Yang, 2014), 음운지식에 기반한 쓰기능력의 발 달을 살펴본 연구들이 보고되고 있다(Lee, 2018). 또한 최근 철자쓰 기에 관한 국내연구에서는 끝소리가 같으나 자소-음소 일치와 불 일치, 형태소 수 등을 조절한 네 가지 유형의 음운규칙이 적용되는 이음절 단어쓰기 과제를 사용하여 언어학습장애 아동과 일반아동 의 철자쓰기 특성을 비교하기도 하였다(Han \& Jung, 2018). 본 연 구에서는 선행연구를 바탕으로 음운지식과 형태지식이 철자쓰기 발달에 어떻게 관련되는지 살펴보기 위해 자소-음소 일치형과 형 태소가 한 개인 자소-음소 불일치형, 형태소가 두 개이면서 단자음 받침인 자소 음소 불일치형, 형태소가 두 개이면서 겹자음 받침인 자소-음소 불일치형 등 네 가지 철자유형으로 구성된 Han과 Jung (2018)의 과제를 사용하여 철자쓰기 발달의 특성을 살펴보았다.

한편 한국어는 글자가 음절단위로 표기되며 소리와 글자의 대응 이 비교적 투명한 언어권에 속한다(Shin et al., 2015). 초등 저학년뿐 아니라 유치원 아동의 경우도 음운정보를 활용한 자소-음소 일치 단어의 정확률이 좋은 편이다(Yang, 2009). 하지만 자소-음소 불일 치 단어의 경우 음운이 결합되는 특정 음운환경에서 소리의 변화 가 많이 나타나는데 이러한 한국어 문법체계에서는 이러한 변화과 정을 몇 가지 규칙에 의해 설명하고 있다. 따라서 한국어 철자쓰기 를 습득하기 위해서는 언어학적 단위에 대한 상위인식능력뿐 아니 라 소리 변동이 일어나는 음운환경의 규칙성을 이해하고 이를 적 용하는 능력이 요구된다(Kim, 2009). Shin과 Park (2015)은 초등 1 학년 국어교과 분석을 통해 연음화, 경음화, 평폐쇄음화, 장애음의 비음화, 격음화, 할락, 자음군 단순화, $j$ 탈락, 구개음화, 유음화 순
서로 음운규칙이 출현하며 특히 연음화, 경음화, 평폐쇄음화, 장애 음의 비음화의 누적 백분율이 $89.93 \%$ 로 나타났다고 보고하였다. 철자쓰기에서 나타난 음운규칙 적용능력을 다룬 한 연구에서 학 년별 철자오류는 일반학생의 경우 1 학년은 경음화, 연음법칙, 7 종 성법, 구개음화, 넘가, ㅎㅌㅌㄹㄹ락, 사잇소리에서 정반응률이 낮았고, 2 학년의 경우 자음군단순화, 3 학년은 7종성법과 구개음화에서 낮 은 수행력을 보였다. 또한 고학년인 4,5 학년의 경우에는 구개음화 (60\%)에서만 낮은 정반응을 보였으나, 6학년 아동은 모든 음운규 칙에서 높은 정반응률을 보였다고 보고하였다(Kim, 2015). 특히 겹받침 쓰기는 고학년이 되어서야 철자수행력이 발달하는 것으로 확인되었다(Lee, 2015). 본 연구에서는 학령기 아동이 습득해야 할 대표적인 음운규칙 유형 네 가지(격음화, 경음화, 연음화, 비음화) 를 중심으로 불일치 단어에서 음운규칙을 적용하는 철자쓰기 발 달의 특성을 살펴보았다.

이에 본 연구에서는 Han과 Jung (2018)에서 사용한 철자쓰기 과 제를 사용하여 초기 철자쓰기 발달적 특성을 살펴보고자 한다. 또 한 지금까지 철자쓰기 발달연구의 대부분이 학령기 중심으로 다루 어져 있어 유치원기 아동에서 학령기 초기에 이르는 주요한 발달과 정을 살펴보는 데 제한이 있었다. Yang (2009)의 연구에서 보고된 바와 같이 유치원 시기부터 음운학적 전략을 주로 사용하면서 철 자발달이 이루어지기 때문에 학령전 시기부터 초기 학령기의 발달 과정을 살펴보는 것이 필요하다. 이는 음운지식이나 형태지식 같은 언어학적 지식이 철자쓰기에 어떻게 영향을 미치는지 살펴볼 수 있 을 뿐 아니라 한국어에 주요 음운규칙이 포함된 철자쓰기의 발달 적 특성도 함께 고려한 과제라는 점에서 초기 철자발달의 두 가지 측면을 살펴보는 데 의미가 있을 것이라고 사료된다.

\section{연구방법}

\section{연구대상}

본 연구는 유치원 아동 및 초등학교 1-3학년 일반아동 총 148 명 을 대상으로 유치원기부터 초등 저학년까지의 철자쓰기의 발달적 특성을 살펴보았다. 연구대상 아동에 유치원 아동을 포함한 것은 Yang (2009)이 유치원 아동기부터 철자쓰기 능력이 발달하기 시작 한다는 연구를 근거로 하였으며, 초등 3학년까지로 선정한 것은 Shin 등(2015)이 초등 3학년까지 가파른 발달 곡선을 보이다 그 이 후는 완만하게 발달한다고 보고한 연구결과를 참고하여 선정하였 다. 아동들은 시각적, 청각적, 인지 및 정서 행동상의 문제가 없으 며, 수용·표현어휘력검사(Receptive \& Expressive Vocabulary Test, REVT; Kim, Hong, Kim, Jang, \& Lee, 2009)의 하위 항목인 수용어 
휘력검사를 실시한 결과 해당 연령 기준 $20 \%$ ile 이상에 속하였다. 또한 학령기 아동은 한국어읽기검사(Korea Language-based Reading Assessment, KOLRA; Pae, Kim, Yoon, \& Jang, 2015)에서 낱말 해독검사를 실시하였고, 그 결과 표준점수 85점 이상인 아동으로 선정하였다. 유치원기 아동의 경우 기초학력검사(Korean Institute for Special Education-basic Academic Achievement Test, KISEBAAT; Park, Kim, Song, Jung, \& Jung, 2008)의 읽기 선수기능검사 에서 -1 표준편차 이상인 아동으로 선정하였다.

\section{검사도구}

대상자 선정도구

수용·표현어휘력검사(REVT)

모든 대상아동들에게 수용·표현어휘력검사(REVT; Kim et al., 2009) 중 수용어휘검사를 실시하여 언어능력 발달 지연 여부를 선 별하였고, 검사 결과 $20 \% \mathrm{ile}$ 이상에 속하는 아동을 대상자 선정 기 준으로 설정하였다.

\section{한국어읽기검사(KOLRA)}

초등 1학년에서 3학년 아동들에게는 한국어읽기검사(KOLRA; Pae et al., 2015) 중 해독 검사를 실시하여 단어읽기에 어려움이 없 는 아동을 선별하였다. 대상자 선정 기준은 표준점수 85 점 이상으 로 설정하였다.

\section{기초학력검사(KISE-BAAT)}

유치원 아동의 읽기능력을 선별하기 위해 기초학력검사의 하위 항목 중 유치원 아동을 대상으로 검사할 수 있는 읽기 선수기능검 사를 실시하여 -1 표준편차 이상인 아동을 대상으로 선별하였다.

\section{본 검사도구}

본 연구에 사용된 철자쓰기검사 과제는 선행연구(Deacon \& Bryant, 2005)를 기반으로 철자유형과 음운규칙을 고려하여 한국 어의 특성에 맞게 제작한 Han과 Jung (2018)의 과제를 사용하였다. Han과 Jung (2018)은 철자유형과 음운규칙을 고려하여 32개 문항 의 철자쓰기 과제를 개발하였는데 검사단어는 최소 3 회 이상 초등 학교 1-3학년 국어과 교과서에 나올 뿐 아니라 Kim (2003)의 '등급 별 국어교육용 어휘'에서 주로 1,2 등급에 해당하는 단어로 선정하 였다.

Han과 Jung (2018)의 과제에서 모든 단어는 끝소리 발음이 같은 2음절 단어로 구성되었으며 철자유형 과제는 영어권 연구에서 사 용한 Deacon과 Bryant (2005)의 과제를 우리말의 특성에 맞게 수
정 및 보완하였다. 이 검사도구는 아동이 음운지식과 형태지식을 적용하여 철자쓰기를 하는지를 보기 위해 자소-음소 일치 여부, 형 태소 수, 겹자음 받침 여부 등을 기준으로 네 가지 철자유형으로 나 누었다. 즉, 음운지식과 관련된 자소와 음소가 일치하는 단어(예: 스키, 꼴찌, 과거, 망고 등)와 형태지식과 관련된 자소-음소 불일치 단어로 크게 나누어 과제를 구성하였다. 불일치 단어의 경우 형태 지식을 반영한 철자쓰기 발달 특성을 구체적으로 살펴보기 위해 형태소가 한 개인 단어(특히, 꼭지, 국어, 망내 등)와 두 개인 단어(좋 기, 먹지, 익어, 막는)로 나누었으며, 형태소가 두 개인 단어의 경우 종성 자음이 홑자음인 것과 겹자음인 것(예: 많기, 밝지, 늙어, 깎는 등)이 포함되도록 하였다.

또한 불일치 단어의 경우 음운 변동의 규칙을 이해하고 읽기와 쓰기에 적용하는 능력이 한국 아동의 철자쓰기 발달에서 중요하게 살펴보아야 하기 때문에 대표적인 음운규칙인 격음화, 경음화, 연 음화, 비음화의 네 가지 규칙이 포함되는 세트로 구성하였다(Han, \& Jung, 2018). 이 네 가지 규칙은 선행연구에 근거하여 초등 교과서 에서 가장 많이 나오는 음운규칙을 중심으로 선정하였다(Han \& Jung, 2018; Lee, 2007; Lee \& Chung, 2002).

이 검사 과제는 단어를 먼저 들려주고, 해당 단어가 포함된 문장 을 예문으로 제시한 다음 다시 목표단어를 들려주어 목표단어 쓰 기로 평가하는 데 이때 사용된 문장은 3-5어절의 단문으로 구성하 고 문장의 주체를 최대한 일관되게 선정하여 문장 이해의 문제가 쓰기에 영향을 미치지 않도록 조절하였으며, 언어병리학을 전공한 박사학위 소지자 2 명, 특수교육을 전공한 박사학위 소지자 1 명에게 타당도 검증을 받은 Likert 척도 5점 만점에 4.9 이상을 받았다(Han \& Jung, 2018).

\section{연구절차}

본 검사는 대상 아동의 학교나 집, 대학 내 언어치료센터 등에 있 는 조용한 방에서 검사자와 대상자 간 일대일로 대면 검사의 형태 로 실시하였다. 검사자는 주 저자를 포함하여 석사학위 과정 대학 원생 6명으로 구성하였으며, 검사실시 전 사전 교육을 통해 검사방 법 및 절차를 충분히 숙지하도록 하였다. 검사자는 본 문항을 평가 하기 전에 예시문항을 활용하여 검사 절차에 대해 아동이 충분히 인지했는지 여부를 확인한 후 본 검사를 실시하였다. 검사 절차는 Deacon과 Bryant (2005)의 연구절차에 따라 목표단어를 불러주 고, 목표단어가 포함된 문장을 들려준 후 다시 목표단어를 들려주 면서 목표단어만 제공된 기록지에 받아쓰도록 하였다. 목표단어 및 문장은 원칙적으로 한 번 들려주었으나 아동이 요청하였을 경 우 단어, 문장, 단어 순서대로 한 번 더 들려주었다. 또한 순서효과 
를 배제하기 위해 검사 문항을 임의로 선정하여 불러주었으며 아 동당 검사에 소요된 시간은 약 10-20분이었다.

\section{자료분석}

채점은 Han과 Jung (2018) 연구의 채점방법을 수정 및 보완하여 실시하였다. 각 단어의 목표철자를 정확하게 철자하였을 경우 1 점, 그렇지 못한 경우 0 점으로 하였고 철자유형별 점수는 일치 단어 8 점, 형태소가 1 개인 불일치 단어 8 점, 형태소가 2 개인 불일치 단어 8 점, 겹자음이 포함된 불일치 단어 8점으로 구성하여 총 32점 만점 으로 채점하였다. 반면 음운규칙별 점수는 자소-음소 불일치 낱말 점수로만 각 음운규칙별 총점을 산정하였는데 격음화 6점, 경음화 6점, 연음화6점, 비음화6점으로 총 24점 만점으로 구성되었다.

\section{자료의 통계처리}

본 연구의 자료 SPSS 20.0 Windows용 프로그램을 이용하여 분 석하였다. 음운규칙과 단어유형에 따른 연령집단 간 차이가 있는 지와 상호작용효과를 살펴보기 위해 반복측정 이원분산분석(repeated two-way ANOVA)을 실시하였고, 두 독립변인의 주효과가 유의미하였을 경우 Scheffé 및 Bonferroni 사후검정을 실시하여 대 응비교 결과를 확인하였다.

\section{신뢰도}

신뢰도를 측정하기 위해 검사 대상자의 $20 \%$ 에 해당하는 총 30 명 아동의 결과지를 제 2 채점자가 독립적으로 채점하게 하여 두 채점 자 간의 일치도를 계산하였다. 제 2 채점자는 언어병리전공 석사과정 학생이며 사전에 검사 문항에 대한 채점기준을 사전 교육한 후 신 뢰도 검사를 실시하였으며, 채점자 간 신뢰도는 $99 \%$ 로 나타났다.

\section{연구결과}

\section{철자유형에 따른 연령집단별 철자쓰기 특성}

철자유형에 따른 연령집단별 철자쓰기 정반응 점수에 대한 결과 는 Table 1 과 같다.

기술통계 결과, 철자유형별 단어의 총점은 자소-음소 일치형을 제외한 모든 유형에서 학년에 따라 평균점수가 상승하는 경향이 나타났다. 반면 자소-음소 일치의 경우 2 학년이 평균 $7.34,3$ 학년이 평균 7.11로 나타나 2 학년의 평균이 다소 높게 나타났다.

이러한 차이가 통계적으로 유의미한 것인가를 확인하기 위해 반 복측정 이원분산분석을 실시한 결과 연령집단 $(F=1,999.08, p<.01)$ 과 단어유형 $(F=177.41, p<.01)$ 에서 주효과가 유의미하게 나타났
Table 1. Descriptive statistics of spelling score according to the types of spelling ( $N=148)$

\begin{tabular}{lcccc}
\hline \multirow{5}{*}{ Type } & \multicolumn{4}{c}{ Spelling score } \\
\cline { 2 - 5 } & $\begin{array}{c}\text { Kindergarten } \\
(\mathrm{N}=30)\end{array}$ & $\begin{array}{c}1 \text { grade } \\
(\mathrm{N}=46)\end{array}$ & $\begin{array}{c}2 \text { grade } \\
(\mathrm{N}=35)\end{array}$ & $\begin{array}{c}3 \text { grade } \\
(\mathrm{N}=37)\end{array}$ \\
\hline MW & $4.50(2.49)$ & $6.65(1.18)$ & $7.34(.68)$ & $7.11(.77)$ \\
1NW & $1.70(1.78)$ & $5.20(1.81)$ & $6.71(1.18)$ & $6.78(1.48)$ \\
2NW & $1.40(1.60)$ & $4.98(2.10)$ & $6.51(1.54)$ & $6.84(1.63)$ \\
DNW & $.30(.79)$ & $2.26(2.21)$ & $4.14(2.11)$ & $5.51(2.19)$ \\
Total & $7.90(5.78)$ & $19.09(4.26)$ & $24.71(4.81)$ & $26.24(5.78)$ \\
\hline
\end{tabular}

Values are presented as mean (SD).

$\mathrm{MW}=$ letter-sound matching word; 1NW= letter-sound non-matching word with one morpheme; 2NW=letter-sound non-matching word with two morphemes; $\mathrm{DNW}=$ letter-sound non-matching word with double consonants.

다. 연령집단 간 차이가 어떤 집단에서 나타난 것인지 알아보기 위 해 Scheffé 사후검정을 실시한 결과 2학년과 3학년 아동집단을 제 외한 모든 집단 간의 통계적 차이가 유의하였다. 즉 연령이 올라갈 수록 철자쓰기 수행력이 증가하다가 초등 2 학년과 3 학년 시기에는 수행력의 차이가 나타나지 않는다는 것을 알 수 있었다. 또한 철자 유형별 주효과가 어떤 유형에서 발생했는지 알아보기 위해 Bonferroni 사후검정을 실시한 결과 불일치 단어의 형태소 한 개 유형과 형태소 두 개 유형 간은 통계적으로 유의한 차이가 나타나지 않았 으나 나머지 유형은 모두 통계적으로 유의한 차이가 나타났다. 아 동들은 자소-음소 일치 단어, 자소-음소 불일치 홑받침 단어, 자소음소 불일치 겹받침 단어 순으로 수행력이 증가하였다. 즉, 자소-음 소 일치 단어를 가장 잘 받아쓸 수 있었으며, 자소-음소 불일치 단 어중 겹받침 단어쓰기를 가장 어려워했다. 한편 자소-음소 불일치 홑받침 단어쓰기에서 형태소 수의 차이는 수행력에 큰 영향을 미 치지 않은 것으로 나타났다.

또한 연령집단과 철자유형 간의 상호작용효과가 유의미하게 나 타났다 $(F=10.88, p<.01)$. 상호작용효과가 어떤 요인들에서 나타났 는지 살펴보기 위해 각 유형별 집단 간 일원배치 분산분석을 실시 한 결과 네 가지 유형 모두 통계적으로 유의한 차이가 나타났다. 자 소-음소 일치 유형의 경우 유치원 아동과 모든 학령기 아동 간의 차 이가 유의하였으나 학령기 아동 1-3학년 간 차이는 유의하지 않았 다 $(F=27.42, p>.01)$. 자소-음소 불일치 유형의 경우 형태소가 한 개 인 단어 $(F=71.06, p>.01)$ 와 두 개인 단어 $(F=63.27, p>.01)$ 모두 2 학년과 3 학년 아동 간의 차이만 유의하지 않았다. 반면 겹받침 불일 치 유형의 경우 모든 집단에서 통계적으로 유의한 차이가 나타났 다 $(F=44.45, p<.01)$. 철자유형에 따른 연령집단별 수행력 차이는 Figure 1에 제시되어 있다. 


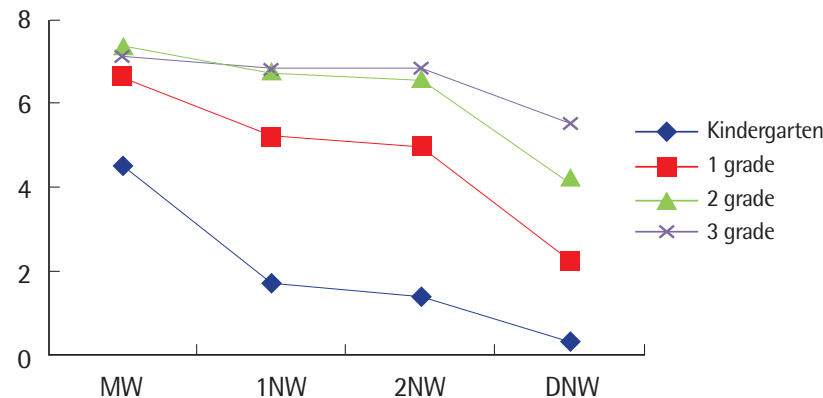

Figure 1. Spelling types according to age. $\mathrm{MW}=$ letter-sound matching word; $1 \mathrm{NW}=$ letter-sound non-matching word with one morpheme; 2NW= letter-sound non-matching word with two morphemes; DNW= letter-sound non-matching word with double consonants.

Table 2. Descriptive statistics of spelling score according to phonological rules $(\mathrm{N}=148)$

\begin{tabular}{lcccc}
\hline \multirow{5}{*}{ Type } & \multicolumn{4}{c}{ Spelling score } \\
\cline { 2 - 5 } & $\begin{array}{c}\text { Kindergarten } \\
(\mathrm{N}=30)\end{array}$ & $\begin{array}{c}1 \text { grade } \\
(\mathrm{N}=46)\end{array}$ & $\begin{array}{c}2 \text { grade } \\
(\mathrm{N}=35)\end{array}$ & $\begin{array}{c}3 \text { grade } \\
(\mathrm{N}=37)\end{array}$ \\
\hline Aspiration & $.23(.63)$ & $2.20(1.86)$ & $3.74(1.74)$ & $4.41(1.66)$ \\
Fortification & $1.13(1.28)$ & $3.30(1.53)$ & $4.09(1.17)$ & $4.70(1.24)$ \\
Lenition & $.67(1.09)$ & $3.07(1.73)$ & $4.63(1.48)$ & $4.95(1.51)$ \\
Nasalization & $1.37(1.73)$ & $3.87(1.33)$ & $4.91(1.10)$ & $5.08(.98)$ \\
Total & $3.40(3.80)$ & $12.43(5.17)$ & $17.37(4.17)$ & $19.14(4.50)$ \\
\hline
\end{tabular}

Values are presented as mean (SD).

\section{음운규칙 유형에 따른 연령집단별 철자쓰기 특성}

철자유형에 따른 연령집단별 철자쓰기 정반응 점수에 대한 결과 는 Table 2와같다.

기술통계 결과, 음운규칙별 단어의 총점은 학년이 올라갈수록 평균점수가상승하고 있으며 이는 모든 유형에서 같은 경향을 나타 냈다. 이러한 차이가 통계적으로 유의미한 것인가를 확인하기 위해 반복측정 이원분산분석을 실시한 결과 연령집단 $(F=1,212.09, p<.01)$ 과 단어유형 $(F=31.72, p<.01)$ 에서 주효과가 유의미하게 나타났다. 연령집단 간 차이가 어떤 집단에서 나타난 것인지 알아보기 위해 Scheffé 사후검정을 실시한 결과 2학년과 3 학년 아동집단을 제외 한 모든 집단 간의 통계적 차이가 유의하였다. 즉 연령이 올라갈수 록 음운규칙에 따른 철자쓰기 수행력이 증가하다가 초등 2학년과 3 학년 시기에는 수행력의 차이가 나타나지 않는다는 것을 알 수 있 었다. 또한 음운규칙별 주효과가 어떤 유형에서 발생했는지 알아보 기 위해 Bonferroni 사후검정을 실시한 결과 경음화와 연음화 규칙 에 통계적으로 유의한 차이가 나타나지 않았으나 나머지 유형은 모 두 통계적으로 유의한 차이가 나타났다. 아동들은 비음화, 연음화, 경음화, 격음화 순으로 수행력이 높았으며, 연음화와 경음화 단어

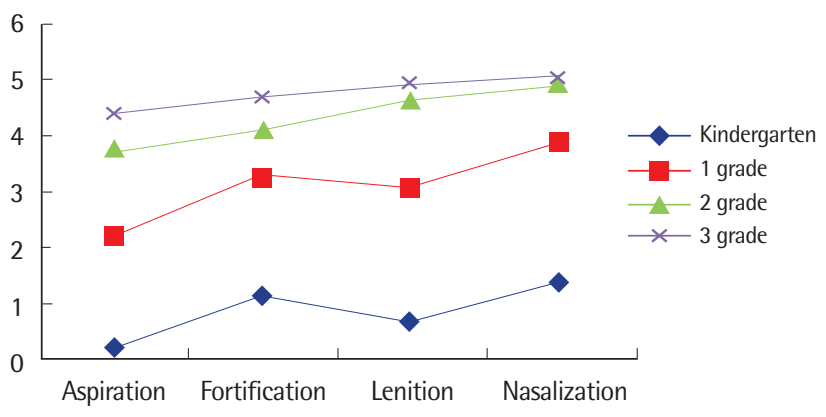

Figure 2. Phonological rules according to age.

받아쓰기는 유사한 수행력을 보이는 것으로 나타났다.

또한 연령집단과 음운규칙 간의 상호작용효과가 유의미하게 나 타났다 $(F=2.29, p<.01)$. 상호작용효과가 어떤 요인들에서 나타났 는지 살펴보기 위해 각 규칙별 집단 간 일원배치 분산분석을 실시 한 결과 네 가지 유형 모두 통계적으로 유의한 차이가 나타났다. 격 음화의 경우 2 학년과 3 학년 간을 제외한 모든 학년의 차이가 유의 하였다 $(F=45.29, p<.01)$. 경음화의 경우 유치원 아동은 모든 학령 기 아동 집단과 유의한 차이가 있었으며 1 학년 집단은 유치원과 3 학년 집단 간의 차이는 유의하였으나 2 학년 집단과는 유의한 차이 가 나타나지 않았다 $(F=43.89, p>.01)$. 연음화의 경우 2학년과 3학 년 집단의 차이만 유의하지 않았고 모든 연령집단 간 차이가 유의 하게 나타났다 $(F=54.30, p<.01)$. 비음화의 경우도 연음화의 경우 와 마찬가지로 2 학년과 3 학년 집단 간에서만 통계적으로 유의한 차이가 나타났다 $(F=55.65, p<.01)$. 음운규칙 유형에 따른 연령집 단별 수행력 차이는 Figure 2에 제시되어 있다.

\section{논의 및 결론}

본 연구는 유치원 아동부터 초등 1-3학년 일반아동을 대상으로 철자유형과 음운규칙유형에 따른 철자쓰기 능력의 발달적 특성을 살펴보았다.

첫째, 연령이 올라갈수록 철자유형이나 음운규칙에 따른 철자 쓰기 수행력이 증가하는 것으로 나타났다. 음운규칙별로 보았을 때는 모든 음운규칙 유형에서 연령이 올라갈수록 철자쓰기 수행력 이 증가하는 경향을 나타냈다. 반면 철자유형별로 볼 때 자소-음소 일치 유형에서 초등 2학년이 3학년에 비해 평균점수가 약간 높은 경향을 나타났다. 이는 철자유형별 분석에서는 자소-음소 일치 유 형이 포함되어 있었으나 음운규칙 유형에서는 자소-음소 불일치 유형만 분석대상에 포함되었기 때문이라고 보인다. 또한 철자유형 별 분석에 포함된 초등 3 학년의 편차..77)가 2 학년의 편차(.68)에 비 
해 다소 컸던 것으로 보아 낮은 점수대에 분포된 비율이 표집된 3학 년 아동들이 2 학년에 비해 높았었을 것으로 추정해 볼 수 있다. 하 지만 철자유형이나 음운규칙 유형에 따른 철자쓰기 능력에 대한 통계검정 결과는 일치하였는데, 초등 2 학년과 3 학년 집단 차이를 제외한 모든 연령집단 간 유의한 차이가 나타났다. 따라서 전반적 으로 유치원기부터 초등 2 학년까지는 철자쓰기 수행력 면에서 가 파른 증가를 보이다가 2 학년에서 3 학년 사이에는 증가추세가 둔해 지는 특성을 보이는 것으로 해석해 볼 수 있다. 이러한 연구결과는 초등 1학년에서 6학년까지 받아쓰기 자료를 분석한 Shin 등(2015) 의 연구에서 자소나 어절쓰기로 본 철자쓰기 정확률이 1,2 학년 간 에서만 유의한 차이가 나타났던 것과 유사하다. 또한 저학년 $(1,2$ 학 년)과 중학년( 3,4 학년) 간 철자쓰기에 유의한 차이가 없었다고 한 Chung (2015)의 연구와도 유사한 결과를 보여주고 있다. 하지만 1-6학년 음운지식 기반 철자쓰기 발달을 살펴본 Lee (2018)의 연구 에서는 5, 6학년을 제외한 모든 연령집단에서 차이가 있었다고 보 고하였는데 이는 본 연구결과와 차이가 있다. 이러한 차이는 선행 연구에서는 자소-음소 일치 유형이 제외되어 있고, 한국어에서 나 타나는 다양한 음운변동 지식에 기반한 단어를 문장쓰기 방식으 로 평가하였기 때문에 본 연구의 과제와는 난이도 면에서 차이가 있어서 나타난 것으로 해석해 볼 수 있다. 특히 본 연구의 겹받침의 경우 모든 연령집단에서 유의미한 차이가 있었는데 이는 난이도가 높은 철자의 경우 초등 저학년기 이후에도 지속적으로 발달하고 있다는 점을 시사해 준다. 본 연구에서 학령기뿐 아니라 유치원기 부터의 철자발달 특성을 살펴보고 유치원기에서 초등 저학년기에 급격한 발달을 이루다 저학년에서 중학년에 이르는 시기에 완만하 게 증가한다는 결과를 보고한 것은 초기 철자발달의 특성을 이해 하는 데 많은 시사점을 제시해 주며, 초등기 입문 시기에 집중적인 철자지도의 필요성에 대한 임상적 근거를 제공해 주고 있다. 하지만 초등 고학년까지 난이도 높은 철자쓰기의 발달을 모두 살펴보지 못한 제한점이 있어 추후 연구에서 다루어지기를 기대해 본다.

둘째, 음운지식이나 형태지식을 반영한 철자유형별 아동의 철자 쓰기 발달능력은 자소-음소 일치 유형을 제외한 세 가지 유형에서 연령이 높아질수록 철자쓰기 수행력이 증가하였다. 다만 앞에서 논의하였듯이 2 학년 집단 평균(7.34)이 3학년 집단 평균(7.11)에 비 해 약간 높았으나 통계적으로는 차이가 없는 것으로 나타났다. 철 자유형에 따른 연령집단별 철자쓰기 능력에 대한 반복측정 이원분 산분석 결과 연령과 철자유형의 주효과와 두 변인 간 상호작용효과 가 유의한 것으로 나타났다. 연령에 따른 주효과는 2,3 학년 집단 간을 제외한 모든 집단 간 차이가 났다. 이러한 결과는 음운지식이 나 형태지식을 반영한 철자쓰기 능력이 유치원기에서 초등 2학년
까지 꾸준히 가파른 증가를 보이다가 초등 2 학년에서 3 학년기 사이 는 완만한 증가를 보이고 있다는 점을 시사해 준다. 자소-음소 일치 유형의 단어쓰기를 모든 아동들이 가장 잘 하였고, 자소-음소 불일 치 단어 중 겹받침 단어를 가장 어려워했다. 철자유형에 따른 주효 과에 대한 사후검정 결과 자소-음소 불일치 홑받침의 두 가지 유형 (형태소 한 개와 두 개인 단어)을 제외한 모든 유형에서 차이가 났 다. 철자유형과 연령집단 간 상호작용효과가 유효하여 각 유형별 집 단 간 수행력의 차이를 살펴본 결과 음운지식을 적용해야 하는 자 소-음소 일치형의 경우 유치원 아동과 초등 1 학년 사이에 유의미한 차이가 있었고, 1 학년 이후 3 학년까지는 완만한 발달을 보이는 것 으로 나타났다. 이러한 결과는 음운지식을 적용한 철자쓰기 능력 이 유치원기부터 발달하여 초등 1 학년에 이르면 거의 완성기에 이 른다는 것으로 해석해 볼 수 있다. 본 연구에서 유치원 아동 집단의 평균점수가 8 점 만점에 4.5 점으로 해당 문항의 $50 \%$ 이상의 쓰기 정확도를 보여줬고 1 학년은 평균 6.65 로 약 $83 \%$ 의 정확도를 보여 자소-일치 유형의 경우 학령기 초기에 빠른 습득을 보이는 것으로 나타났다. 이는 Yang (2009)의 연구에서 유치원 아동들이 음운전 략을 활용하여 기본 초성 및 몇 가지 종성 자음쓰기를 정확히 수행 하는 것으로 나타난 것과 유사한 결과이다. 따라서 본 연구결과는 우리 나라 아동의 경우 유치원 시기부터 음운지식을 적용한 철자 쓰기가 가능하고 초등 입학을 전후로 한 시기에 급격한 발달을 보 이므로 이 시기의 자소-음소 일치 유형의 음운지식을 적용한 쓰기 지원이 중요하게 이루어져야 한다는 점을 시사해 준다.

한편 5-10세 아동을 대상으로 연구한 Deacon과 Bryant (2005) 는 어린 아동들도 1 형태소 단어보다 2형태소 단어를 더 정확하게 철자함으로써 초기 철자쓰기 발달단계부터 형태지식을 사용하는 것으로 나타났다. 이러한 외국 선행연구를 토대로 본 연구에서는 두 가지 유형 과제에서의 수행력을 비교하여 형태지식의 사용능력 을 살펴보고자 하였다. 하지만 연구결과 자소-음소 불일치 홑받침 의 경우 두 유형 간 차이가 유의하지 않았는데 이는 초등 저학년의 경우 음운지식을 주로 사용하며 형태지식을 사용하는 데 어려움 이 있다고 한 Henderson (1990)의 연구를 지지해 주는 결과이다. 또한 최근 우리나라 일반아동과 언어학습장애 아동을 대상으로 같은 과제를 적용한 연구에서 자소-음소 불일치 홑받침이 두 유형 단어에서 형태소 수에 따른 차이가 나지 않았다는 Han과 Jung (2018)의 연구결과와 유사하다. 몇몇 외국연구에서와 달리 우리 나 라 아동의 경우 유치원에서 초등 3 학년까지의 이음절 자소-음소 불 일치 철자쓰기를 할 때 형태소 지식을 더 잘 활용한다고 보기 어렵 다고 해석해 볼 수 있다(Deacon \& Bryant, 2005; Sangster \& Deacon, 2011; Treiman et al., 1994). 그런데 외국의 선행연구에서는 초 
등 저학년의 경우 형태지식의 적용 유무에 대해서는 일관되지 않는 결과를 보고하고 있다(Deacon \& Bryant, 2005; Henderson, 1990; Sangster \& Deacon, 2011; Treiman et al., 1994). 또한 Han과 Jung (2018)의 연구에서는 1 형태소 단어에서보다 2 형태소 단어에서의 차이가 좀 더 크게 나타났고, 일반아동의 경우 통계적 차이는 없지 만 2형태소 단어의 평균이 조금 높은 경향을 보여주었다는 점에서 언어적 지식이 약한 아동들이 특히 형태전략의 사용이 어려울 것 을 예측하였다. 하지만 본 연구에서는 거의 차이는 없었지만 1 형태 소 단어 $(\mathrm{M}=5.24, \mathrm{SD}=2.48)$ 가 2 형태소 단어 $(\mathrm{M}=5.08, \mathrm{SD}=2.67)$ 에 비해 평균점수가 약간 높아 선행연구에서 나타난 경향과 일치하 지 않았다. 이는 선행연구에서는 학령기 아동만을 대상으로 하였 으나, 본 연구에서는 유치원 아동이 포함되었기 때문인 것으로 해 석해 볼 수 있지만 초기 철자쓰기 발달에서 형태지식의 영향력에 대한좀 더 많은 후속연구가 필요할 것으로 사료된다.

단어유형 중 겹받침 단어의 경우 모든 아동들의 가장 어려워하는 것으로 나타났다. 이 유형의 경우 사후검정에서 모든 연령집단 간 차이가 통계적으로 유의하여 유치원부터 초등 3 학년까지 지속적으 로 겹받침이 포함된 불일치 단어쓰기 능력이 발달하고 있는 것으로 나타났다. 특히 유치원기 아동들의 평균값이 .3 (표준편차 .79)으로 바닥효과가 나타났다. 즉 이러한 결과를 토대로 볼 때 겹받침 쓰기 는 학령기에 들어서서 발달이 이루어지며 중학년기 이후에도 지속 적으로 발달하는 것으로 해석해 볼 수 있다. 본 연구에서는 초등 3 학년까지 철자쓰기 능력을 살펴보았기 때문에 이 철자유형에 대한 초등 중학년 이후 고학년에 이르기까지의 발달 과정을 살펴보는 데 는 제한이 있었다. 추후연구에서 이러한 점을 보완하여 초등 고학년 기까지 확장한 철자쓰기 발달 연구가 이루어지길 기대해 본다.

셋째, 음운규칙에 따른 아동의 철자쓰기 능력 역시 연령이 증가 함에 따라 모든 음운규칙 유형에서 단어쓰기 수행력이 높아지며 유치원에서 초등 2 학년까지 유의미한 증가추세를 보이다가 초등 2 학년 이후 3 학년까지는 완만한 발달을 이루는 것으로 나타났다. 음 운규칙 유형별로는 비음화, 연음화, 경음화, 격음화 순으로 수행력 이 높게 나타났는데 이러한 차이가 통계적으로 유의하였다. 음운규 칙 유형별 차이에 대한 사후검정 결과 연음화와 경음화 규칙 사이 의 평균차이는 유의하게 나타나지 않았으나 나머지 규칙들 사이에 서는 통계적으로 유의한 차이가 났다. 이는 Han과 Jung (2018)의 연구결과와 음운규칙의 평균 수행력의 순서는 유사하게 나타났으 나 이 연구에서는 격음화와 비음화, 경음화와 비음화 간의 통계적 차이만 유의미하여 세부 규칙별로는 다소 차이 나는 결과를 보여 주었다. 이는 Han과 Jung (2018)의 연구는 언어학습장애 아동과 일반아동이 포함되어 있어 대상자의 차이가 영향을 미친 것으로
해석해 볼 수 있다. 쓰기과제는 아니지만 읽기과제에서 초등 저학년 이 기식음화 비음화, 된소리화 순으로 오류가 높게 나타났다고 보 고한 Kim과 Pae (2011)의 연구결과와 비교해 볼 때 비음화와 된소 리화에서 순서의 차이가 있지만 격음화를 가장 어려워한다는 점에 서는 유사한 결과이다. 이러한 결과에 근거해 볼 때 음운규칙이 포 함된 철자쓰기에 대한 평가 및 중재 시 격음화의 난이도를 좀 더 고 려할 필요가 있음을 알 수 있다. 한편 연령집단과 음운규칙 유형에 따른 상호작용효과도 유의하였는데 연음화, 비음화, 격음화는 2 학 년과 3학년 간에서만 차이가 나타나 유사한 패턴을 보였으나 경음 화의 경우 1,2 학년과 2,3 학년 간의 차이가 유의하지 않았다. 이는 연음화, 비음화 격음화는 유치원 시기에서 초등학교 2학년 시기까 지 상승하며 발달하지만 초등 2 학년에서 3 학년 사이는 완만한 발 달을 보인다는 것으로 해석할 수 있다. 그런데 경음화의 경우 유치 원에서 초등 1 학년까지 발달이 가파르지만 1 학년 이후 완만하게 발 달하는 특성을 보여 다른 규칙들과 다른 패턴이 나타났다.

유치원기부터 초등 저학년까지 철자유형 및 음운규칙 유형에 따 른 철자쓰기 발달특성을 살펴본 본 연구결과는 초기 철자쓰기 발 달의 특성을 이해하고 평가 및 중재하는 데 음운지식이나 형태지 식 등의 언어학적 지식과 음운규칙 적용의 특성을 고려해야 할 필 요성이 있음을 시사해 주고 있다. 무엇보다 자소-음소 일치 음운지 식을 반영한 철자쓰기의 경우 초등 입문기에 습득능력이 급격하게 상승한다는 연구결과는 초기 철자쓰기를 평가하고 중재할 때 음 운지식 적용원리에 대한 지원이 중요함을 다시 한번 강조해 주고 있 다. 자소-음소 불일치 철자쓰기의 경우 겹자음 받침이 포함된 단어 는 가장 난이도가 높고 초등 3 학년의 경우도 오류가 많이 나타나므 로 초등 고학년기까지 철자쓰기 완성을 위해 지속적 지원이 이루어 져야 할 필요가 있음을 보여주었다. 다만 본 연구에서는 홑자음 받 침의 자소-음소 불일치 단어에서 형태소 수가 철자쓰기에 크게 영 향을 끼치지 않는 것으로 나타나 유치원기에서 초등 저학년 시기까 지 철자쓰기에 형태지식을 많이 적용하지는 않고 있음을 보여주었 다. 하지만 대상 수나 다양한 연령집단이 포괄되지 못한 제한점이 있어 이를 일반화해서 해석하기에는 제한점이 있으므로 초등 중학 년과 고학년으로 확장한 다수의 후속연구로 지속적인 규명이 필요 할 것으로 사료된다. 또한 한국어는 자소-음소 불일치 철자쓰기에 서 다양한 음운규칙의 이해 및 적용이 중요한데, 음운규칙에 따른 발달적 특성을 살펴본 본 연구결과에 근거해 볼 때 학령기 아동의 철자쓰기 평가 및 중재에서 음운규칙별 난이도를 고려해야 한다는 점을 알 수 있었다. 


\section{REFERENCES}

Bear, D. R., Invernizzi, M., Templeton, S., \& Johnston, F. R. (2012). Words their way: word study for phonics, vocabulary, and spelling instruction. Boston, MA: Pearson/Allyn and Bacon.

Berninger, V. W., Abbott, R. D., Jones, J., Wolf, B. J., Gould, L., AndersonYoungstrom, M., ... \& Apel, K. (2006). Early development of language by hand: composing, reading, listening, and speaking connections; three letter-writing modes; and fast mapping in spelling. Developmental Neuropsychology, 29(1), 61-92.

Cho, J., \& Kim, E. (2000). Early childhood language education. Seoul: Jeongminsa.

Chung, B. J. (2015). Orthographic awareness and related components in children in grade 1 through 4. Journal of Speech-Language \& Hearing Disorders, 24(24), 63-71.

Daffern, T., Mackenzie, N. M., \& Hemmings, B. (2015). The development of a spelling assessment tool informed by Triple Word Form Theory. Australian Journal of Language and Literacy, 38(2), 72-82.

Deacon, S. H., \& Bryant, P. (2005). What young children do and do not know about the spelling of inflections and derivations. Developmental Science, 8(6), 583-594.

Ehri, L. C. (1985). Learning to read and spell. Paper presented at Annual Meeting of the American Educational Research Association, Chicago, IL.

Gentry, J. R. (1982). An analysis of developmental spelling in "GNYS AT WRK". The Reading Teacher, 36(2), 192-200.

Gentry, J. R. (2000). A retrospective on invented spelling and a look forward. The Reading Teacher, 54(3), 318-332.

Han, S. I., \& Jung, K. H. (2018). Spelling characteristics of early grade elementary school children with language learning disabilities. Communication Sciences \& Disorders, 23(2), 313-326.

Henderson, E. H. (1990). Teaching spelling (2nd ed.). Boston, MA: Houghton Mifflin.

Jung, S. I. (2005). Invented spelling: spelling error analysis in Korean kindergarten children (Master's thesis). Ewha Womans University, Seoul, Korea.

Kamhi, A. G., \& Catts, H. W. (2012). Language and reading disabilities (3rd ed.). Boston, MA: Allyn and Bacon.

Kim, A. H. (2009). Spelling skills of elementary students in Korea: focusing on spelling accuracy and error patterns. Journal of Elementary Education, 22(22), 85-113.

Kim, A. H. (2013). A preliminary study on predictors for elementary students' writing. Communication Sciences \& Disorders, 18(1), 66-75.

Kim, K. (2003). Vocabulary for Korean education by level. Seoul: Pagijung.

Kim, M., \& Pae, S. (2011). The decoding development of Korean children in word reading. Korean Journal of Communication \& Disorders, 16(2), 143153.

Kim, Y. T., Hong, G. H., Kim, K. H., Jang, H. S., \& Lee, J. Y. (2009). Receptive \& expressive vocabulary test (REVT). Seoul: Seoul Community Rehabilitation Center.

Kim, Y. W. (2015). A comparison of word recognition and spelling skills between students with reading disabilities and without disabilities. The Journal of Special Education: Theory and Practice, 16(4), 363-386.

Lee, C. (2007). Principle of grammar education in elementary school. The Journal of Korean Language and Literature Education, 41, 127-148.

Lee, E. K. (2018). A study on the writing developmental characteristics of school-aged children based on phonological knowledge. Journal of SpeechLanguage \& Hearing Disorders, 27(1), 69-82.

Lee, H. M. (2015). Orthographic ability in terms of grade and reading knowledge (Master's thesis). Hallym University, Chuncheon, Korea.

Lee, K., \& Chung, M. (2002). Statistical analysis of Korean phonological variations using grapheme-to-phoneme system. The Journal of the Acoustical Society of Korea, 21(7), 656-664.

Masterson, J. J., \& Apel, K. (2007). Spelling and word-level reading: a multilinguistic approach. In A. G. Kamhi et al. (Eds.), Clinical decision making in developmental language disorders (pp. 249-266). Baltimore, MD: Paul H Brookes Publishing.

Nagy, W., Berninger, V. W., \& Abbott, R. D. (2006). Contributions of morphology beyond phonology to literacy outcomes of upper elementary and middle-school students. Journal of Educational Psychology, 98(1), 134-147.

Nunes, T., Bryant, P., \& Bindman, M. (1997). Morphological spelling strategies: developmental stages and processes. Developmental Psychology, 33(4), 637-649.

Pae, S., Kim, M., Yoon, H. J., \& Jang, S. (2015). Korean Language Based Reading Assessment (KOLRA). Seoul: Hakjisa.

Park, G., Kim, G., Song, Y., Jung, D., \& Jung, I. (2008). Korea Institute for Special Education-Basic Academic Achievement Test (KISE-BAAT). Ansan: Korea Institute for Special Education.

Park, H. O., \& Chung, Y. S. (2008). A study on dictation errors and dictation error characteristics of the elementary student. The Journal of Special Education: Theory and Practice, 9(4), 367-395.

Read, C. (1986). Children's creative spelling. London: Routledge. 
Kyung Hee Jung • Developmental Characteristics for Spelling of Kindergarten to 3rd Grade

Rubin, H. (1988). Morphological knowledge and early writing ability. Language and Speech, 31(4), 337-355.

Sangster, L., \& Deacon, S. H. (2011). Development in children's sensitivity to the role of derivations in spelling. Canadian Journal of Experimental Psychology, 65(2), 133-142.

Shin, G. Y., Seol, A. Y., Cho, H. S., Nam, K. C., \& Pae, S. (2015). Korean spelling development and linguistic patterns. Journal of Speech-Language \& Hearing Disorders, 24(2), 61-72.

Shin, H. J., \& Park, H. J. (2015). An analysis of the occurrence of syllables, phonemes and phonological rules in first grade elementary Korean language text books. Journal of Speech-Language \& Hearing Disorders, 24(4), 125-133.
Treiman, R., Cassar, M., \& Zukowski, A. (1994). What types of linguistic information do children use in spelling? The case of flaps. Child Development, 65(5), 1318-1337.

Yang, M. (2009). Spelling development of kindergarten students: a one year longitudinal study. Korean Journal of Communication \& Disorders, 14(1), 14-33.

Yang, M. (2014). Children's spelling of phonological and morphological features in primary grades. Communication Sciences \& Disorders, 19(1), 120131.

Yang, M., \& Lee, A. J. (2016). Influences of linguistic awareness on primary grade children's spelling abilities. Korea Journal of Learning Disabilities, 13(13), 67-90. 


\section{국문초록}

\section{유치원에서 초등 3학년 아동의 철자쓰기 발달 특성}

\section{정경희}

용인대학교 재활복지대학원 언어치료학과

배경 및 목적: 본 연구는 유치원 아동부터 초등 1-3학년 일반아동을 대상으로 단어유형과 음운규칙 유형에 따른 철자쓰기 능력의 발 달적 특성을 알아보고자 하였다. 방법: 연구대상은 유치원 40 명, 초등 1 학년 46 명, 초등 2 학년 35 명, 초등 3 학년 37 명으로 총 148 명의 일 반아동을 대상으로 하였다. 연구도구는 네 가지 철자유형과 네 가지 음운규칙이 포함된 단어를 선정하여 받아쓰기를 실시하였다. 결 과: 첫째, 연령이 올라갈수록 단어유형이나 음운규칙에 따른 철자쓰기 수행력이 증가하였다. 초등 2 학년과 3 학년 집단에서는 차이가 유의하지 않았으나 나머지 집단은 모두 통계적으로 유의한 차이가 났다. 둘째, 단어유형 중 자소-음소 불일치 홑자음 두 가지 유형을 제 외한 나머지 유형의 차이가 유의하였다. 자소-음소 일치 단어는 유치원과 초등 6학년 간 유의한 차이가 났고, 자소-음소 불일치 겹자음 은 모든 학년에서 유의한 차이가 났다. 셋째, 음운규칙에 따른 아동의 수행력은 비음화 연음화, 경음화, 격음화 순서대로 높게 나타났다. 논의 및 결론: 본 연구결과를 통해 유치원기부터 초등 저학년까지 철자쓰기 발달의 특성을 이해할 수 있었으며, 철자쓰기 평가 및 중재 에 대한 시사점을 논의하였다.

핵심어: 유치원 아동, 학령기 아동, 철자쓰기, 철자유형, 음운규칙

본 논문은 용인대학교 교내 학술지원비를 받아서 연구되었음.

\section{참고문헌}

김광해(2003). 등급별 국어교육용 어휘. 서울: 박이정.

김미배, 배소영(2011). 낱말읽기에서의 초등학생 음운해독력 발달. 언어청각장애연구, 16(2), 146-153.

김애화(2009). 초등학교 학생의 철자특성 연구: 철자발달 패턴 및 오류 유형 분석. 초등교육연구, 22(4), 85-113.

김애화(2013). 초등학교 학생의 쓰기능력 예측변인에 관한 예비 연구. Communication Sciences \& Disorders, 18(1), 66-75.

김영태, 홍경훈, 김경희, 장혜성, 이주연(2009). 수용·표현어휘력검사(REVT). 서울: 서울장애인종합복지관.

김용욱(2015). 읽기장애학생과 일반학생의 단어인지와 철자법 특성 비교. 특수교육저널: 이론과 실제, 16(4), 363-386.

박경숙, 김계옥, 송영준, 정동영, 정인숙(2008). 기초학력검사(Korea Institute for Special Education-Basic Academic Achievement Test, KISE-

BAAT). 안산: 국립특수교육원.

박혜옥, 정용석(2008). 초등학생 받아쓰기 발달과 오류 특징에 관한 연구. 특수교육저널; 이론과 실천, 22(3), 367-395.

배소영, 김미배, 윤효진, 장승민(2015). 한국어 읽기검사(KOLRA). 서울: 학지사.

신가영, 설아영, 조혜숙, 남기춘, 배소영(2015). 초등학생의 철자 발달과 오류 패턴 분석. 언어치료연구, 24(2), 61-72.

신혜정, 박희정(2015). 초등학교 1학년 국어 교과서의 음절, 음소 및 음운규칙 출현 빈도 분석. 언어치료연구, 24(4), 125-133.

양민화(2009). 유치원 아동의 철자발달 단기종단연구. 언어청각장애연구, 14(1), 14-33.

양민화(2014). 음운론적 유형과 형태론적 유형의 초기 철자발달. Communication Sciences \& Disorders, 19(1), 120-131.

양민화, 이애진(2016). 학령기 초기 아동의 철자 기술에 미치는 언어학적 인식 능력의 영향력 변화. 학습장애연구, 13(3), 67-90.

이경님, 정민화(2002). 발음열 자동 생성기를 이용한 한국어음운변화 형상의 통계적 분석. 한국음향학회지, 21(7), 656-664.

이은경(2018). 학령기 아동의 음운지식기반 쓰기능력 발달 특성. 언어치료연구, 27(1), 69-82.

이창근(2007). 초등학교 문법 교육의 접근 원리. 국어교육연구, 41, 127-148.

이혜민(2015). 학년과 읽기수준에 따른 철자 수행력. 한림대학교 대학원 석사학위논문. 
정부자(2015). 초등 1-4학년 아동의 철자인식 발달특성과 관련 요인. 언어치료연구, 24(3), 63-71.

정상임(2005). 5-6세 아동의 창안적 글자쓰기 발달 단계에 따른 오류 유형 분석. 이화여자대학교 대학원 석사학위논문.

조정숙, 김은심(2000). 유아언어교육. 서울: 정민사.

한송이, 정경희(2018). 초등 저학년 언어학습장애아동의 철자쓰기 특성. Communication Sciences \& Disorders, 23(2), 313-326.

\section{ORCID}

정경희(http://orcid.org/0000-0002-1816-0171) 